\title{
Vertical Electrical Sounding (VES. Investigation of Aquifer and Potential Clay Materials in Douala Subbasin (Cameroon, Central Africa)
}

\author{
Michel Bertrand Mbog ${ }^{1}$, Gilbert François Ngon Ngon ${ }^{2}$, Jacques Etame ${ }^{2}$, Anatole E Djieto Lordon ${ }^{3}$, Bernard \\ Tassongwa $^{1} \&$ Paul Bilong ${ }^{4}$ \\ ${ }^{1}$ Department of earth science Faculty of sciences University of Dschang, Cameroon \\ ${ }^{2}$ Department of earth science Faculty of sciences University of Douala, Cameroon \\ ${ }^{3}$ Department of earth science Faculty of sciences University of Buea, Cameroon \\ ${ }^{4}$ Department of earth science Faculty of sciences University of Yaoundé, Cameroon \\ Correspondingauthor: Michel Bertrand MBOG, Department of earth science Faculty of sciences University of \\ Dschang, $\quad$ BP: $67 \quad$ Dschang, $\quad$ Cameroon. \\ michel.mbog@univdschang.org/michelbertrandmbog@yahoo.fr/gngonnogon@yahoo.fr/etame.jacques@yahoo.f \\ r/alordon@yahoo.com/Bernard.tassongwa@univdschang.org/btassongwa2004@yahoo.fr/paul.bilong@yahoo.fr
}

Received: December 19, 2015

Accepted: January 6, 2016

Online Published: January 28, 2016

doi:10.5539/esr.v5n1p94

URL: http://dx.doi.org/10.5539/esr.v5n1p94

\begin{abstract}
Vertical electrical sounding was done at 47 points using an ABEM 1000 Terrameter and a set of cables that could probe up to a depth of $500 \mathrm{~m}$. Resistivity was determined in two sites located in the district of Douala III (Bomkoul and Ngoma) $6 \mathrm{~km}$ west of the main town on the left bank of the Wouri River. The choice of these neighbourhood is as a result on the one hand, the presence of clay deposits from which sections have helped to configure resistivity data with those of geoelectric sections, and on the other hand, by the ability to extend the measuring device over great distances without being hindered by urbanization. The depths of investigation range from a minimum of $30 \mathrm{~m}$ and a maximum of $120 \mathrm{~m}$. The results show a wide variability in resistivity values throughout the study area; it may be related to the high variability of facies described on sections by diggers. This variability may be due to the complexity of deposits recorded in the Douala sedimentary basin and also because of the presence of water in both sandy and clay sediments due to climate. The suggested resistivity is between 20 and $600 \mathrm{ohm} . \mathrm{m}$ for clays and greater than $1000 \mathrm{ohm} . \mathrm{m}$ for sand. Given the weak thickness of some layers, the cancellation phenomena that affect very thin layers between two layers of different geoelectric properties of the latter have been observed, thus assigning to clay layers, sand resistivity.
\end{abstract}

Keywords: Gulf of Guinea, Douala Sedimentary Basin, vertical electrical surveys, sections, apparent resistivity, true resistivity

\section{Introduction}

Geologists make use of direct and visual observations to examine rocks that show on the surface, study them and deduce the architecture of the substratum. Geophysicist also try to determine the architecture or geometry of the hidden substratum by measuring certain physical properties from the surface. There are many geophysical methods, each providinges guidance on the nature of the substratum via the study of changes in physical parameters. Geophysics thus is essentially based on the measurement of contrasts in the materials' physical properties of the substratum and an attempt to deduce the nature and distribution of materials responsible of these observations (Chapellier \& Mari, 2000).

Most geophysical studies carried out so far in the Douala basin were conducted by oil companies, whose ultimate goal is the search for oil. This implies investigations at depths neglecting surface formations. Other geophysical studies have been carried out by drilling companies, but only in order to solve specific problems. Geophysical data, especially data obtained through electrical methods in the basin is very scanty, specifically in terms of the subsurface.

This study focuses on the determination of apparent resistivity of sediments in Bomkoul and Ngoma areas of the 
Douala subbasin, using the electrical surveys method. The objective of this work is to assign a range of resistivity values for each type of sediment found in the study areas. This will lay the foundation for a qualitative geoelectric characterization of lithological variations of superficial formations in the Douala sedimentary basin. The results of this study could have application in various fields of geology. In hydrogeology for example, they could be important in the search ground water, or in environmental geology the setting up the depositional models which can be used to infer depths and quantities of clays, as far as the search for clay materials level is concerned.

\subsection{Description of the Study Area}

The Douala subbasin is situated between $3^{\circ} 00^{\prime}$ and $4^{\circ} 30^{\prime}$ North latitude and $9^{\circ} 20^{\prime}$ and $10^{\circ} 10^{\prime}$ East longitude and covers an area of approximately $12,000 \mathrm{~km}^{2}$. The study sites are Bomkoul and Ngoma which are districts of the Douala III municipality and between $4^{\circ} 05$ 'and $4^{\circ} 10^{\prime}$ North latitude and $9^{\circ} 45^{\prime}$ and $9^{\circ} 50^{\prime}$ East longitude (Fig.1)

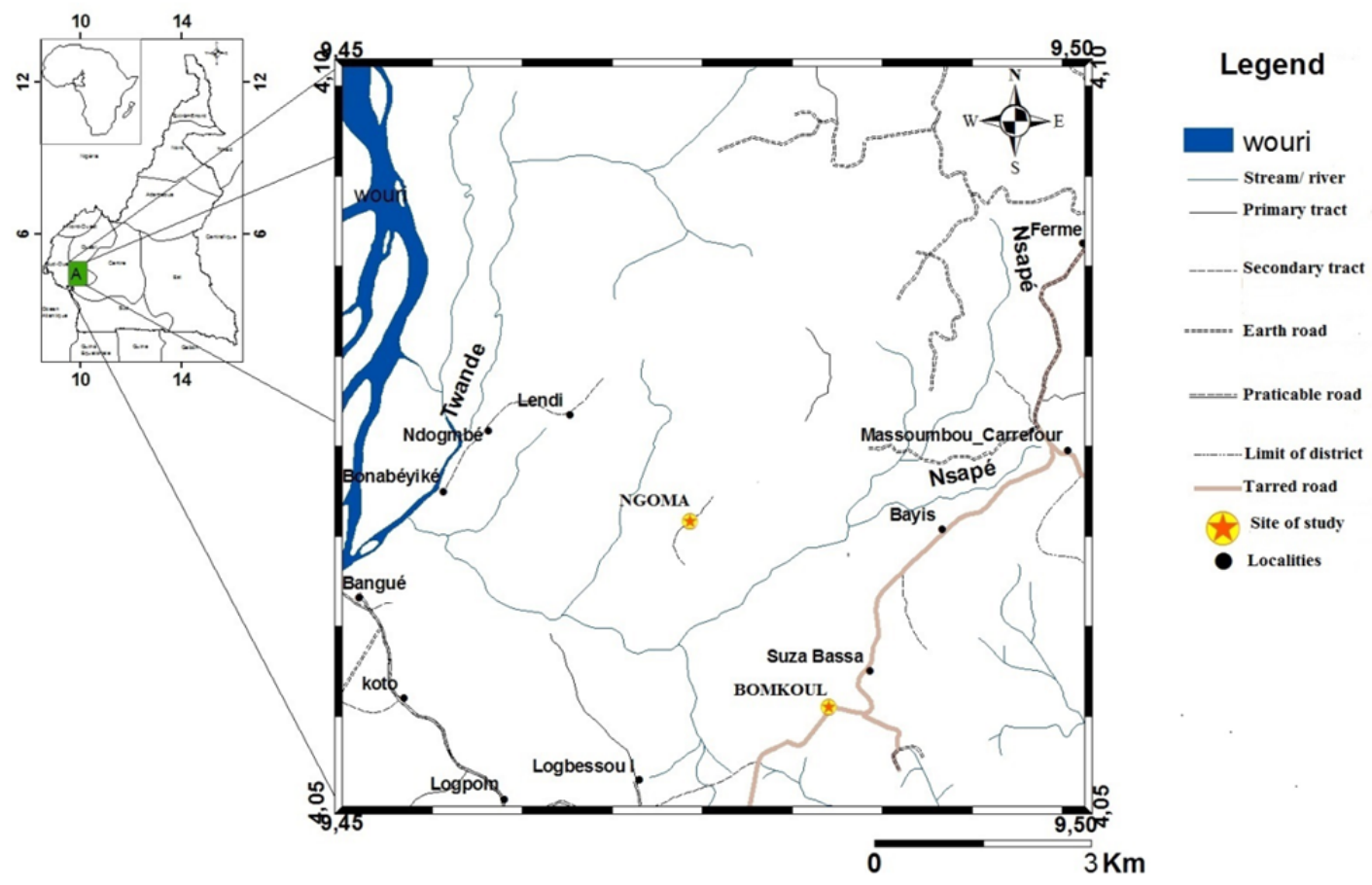

Figure 1. Map of the study area Represents the localisation map of the study area

\subsection{Methodology}

The method used is the electrical surveys which principle is based on the identification of soil layers using their resistivity (Castany, 1982; Detay, 1993; Fetter, 1994; Chapellier \& Mari, 2000; Giliet al., 2004). Several devices can be used: Wenner, dipoledipole, Schlumberger (Dubois \& Diament, 2005). The device used in this study is the one of Schlumberger.

The resistivity of the soil varies according to two main parameters: the lithological nature, water content and water mineralization.

The determination of these resistivities is done by interpreting the electrical surveys datas. The realization of electrical surveys is by injecting current (I. using two electrodes A and B. It creates an equipotential network among which two curves in particular come to the surface at $\mathrm{M}$ and $\mathrm{N}$ (receiving electrodes. and enables measurement of the potential difference (Meyer Stadelhofen, 1991; Collin, 2004).

Thus, depending on the geological context, one can from the resistance values, determine the lithological nature of the soils encountered (Chapellier, 1987; Dubois Diament, 2005; Chiarelli, 2008).

The potential difference is:

$$
\Delta V=V_{M} V_{N} \quad \text { with } \quad V_{M}=\frac{\rho I}{2 \pi}\left(\frac{1}{A M}-\frac{1}{B M} . \quad \text { and } \quad V_{\mathrm{N}}=\frac{\rho I}{2 \pi}\left(\frac{1}{A M}-\frac{1}{B M}\right. \text {. }\right.
$$




$$
\Delta V=\frac{1}{2 \pi}\left(\left(\frac{1}{A M}-\frac{1}{A N}\right)-\left(\frac{1}{B M}-\frac{1}{B N}\right) \cdot \rho I\right.
$$

We deduce the resistivity by the formula: $\boldsymbol{\rho}=\mathbf{K} \frac{\Delta \mathbf{V}}{\boldsymbol{I}}$

$\rho$ is expressed in ohm.m, $\Delta \mathrm{V}$ is in $\mathrm{mV}$ and $\mathrm{i}$ in $\mathrm{mA}, \mathrm{K}$ (geometric factor. is a coefficient depending on the geometry of the quadrupole AMNB and is expressed in metres (Meyer de Stadelhofen, 1991).

The method of resistances by electrical surveys is a quantitative interpretation (Astier, 1971; Meyer Stadelhofen, 1991; Abrego, 2007).

After carrying out field measurements, key elements enable the interpretation the data collected:

By solving the general equation of potential at the surface of two parallel, homogeneous and isotropic soils, we can construct a sequence of curves representing the apparent resistivity (Chapellier\& Mari, 2000).

All these curves carry the abacus name $\mathrm{CH} 1$. These curves represent $\rho \mathrm{a} / \rho 1$ according to OA / h1 for different values of $\rho \mathrm{a} / \rho 1(\mathrm{OA}=\mathrm{AB} / 2)$. They are plotted on a loglog scale. Each curve of the abacus matches with a curve of an electric survey run on a substratum composed of two soils with the first soil having a unit thickness and resistivity (Chapellier \& Mari, 2000).

The graphical interpretation of these surveys shows differences depending on whether the surveys are based on two or three soils (Meyer Stadelhofen, 1991; Girard, 2010).

\subsection{Results and Interpretation}

Figure 2 presents the different survey points in the study area. The surveys were carried out in Bomkoul and Ngoma. The lithological data of these sections will be used for correlations with the resistivity data.

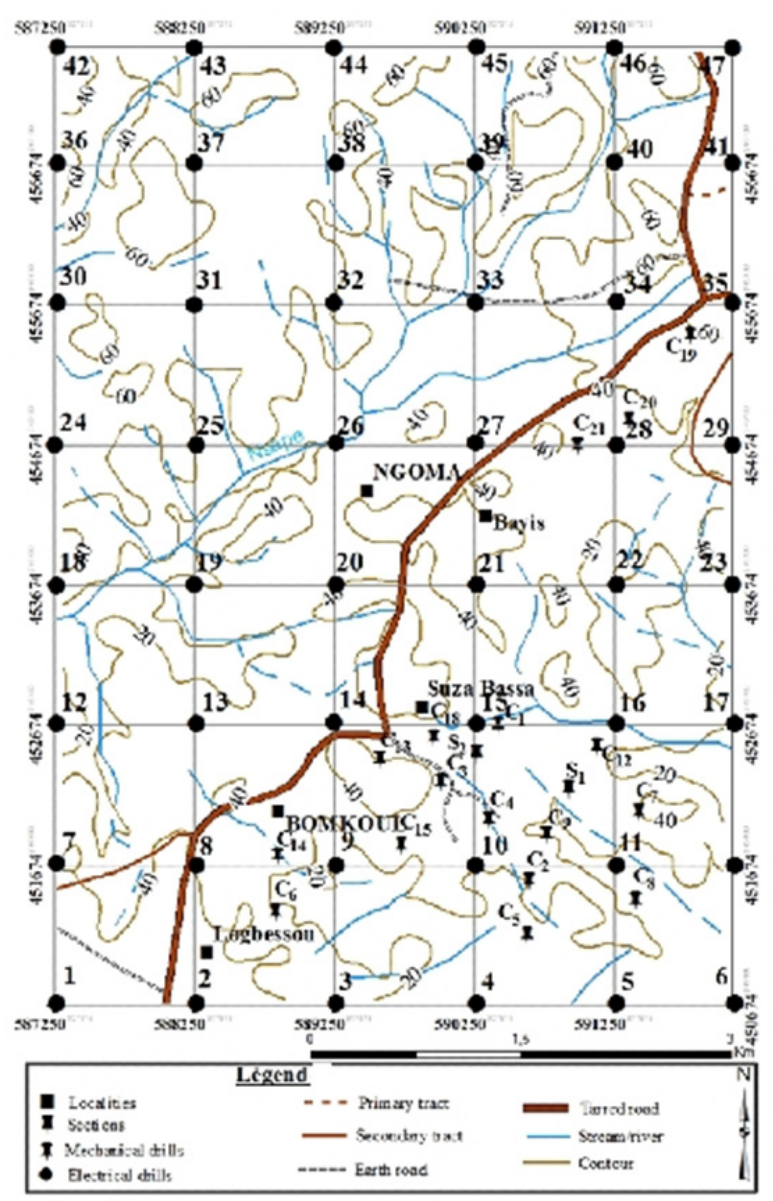

Figure 2. Map of electric surveys Represents the map of the survey points and section in the study area 


\subsection{Description Outcrops}

In Bomkoul and Ngoma, clays, silts, sandstones, nodular clays constitute the major field macroscopic differentiated facies. Several traditional sections located at different topographical levels have revealed thick clay deposits $(610 \mathrm{~m})$ and bottom to top, surmounted by materials representing almost the entire surface of the area with local variations. Fifteen lithofacies were identified and described in Table 1, in the eight representative sections including six in Bomkoul and two in Ngoma. Their presence in lithologic sections depends on their topographic position: on the upper, medium or lower slopes.

Table 1. List of facies codes and corresponding lithologies (modified from Miall, 1978 and Postma, 1990)

\begin{tabular}{|c|c|c|c|c|}
\hline $\begin{array}{l}\text { Facies } \\
\text { codes }\end{array}$ & Descriptions & Colour & Sedimentary Structures & Deposit process \\
\hline $\mathrm{S} 1$ & $\begin{array}{l}\text { Sandstone medium to coarsegrained } \\
(30 \mathrm{~cm} \text { to } 2 \mathrm{~m} \text { thickness. }\end{array}$ & $\begin{array}{l}5 \mathrm{Y} 7 / 6 \text { to } \\
5 \mathrm{R} 4 / 6 \text { to } 8 / 1\end{array}$ & $\begin{array}{l}\text { horizontal laminations, oblique } \\
\text { ferruginous massive red }\end{array}$ & Cohesive debris flows \\
\hline $\mathrm{S} 2$ & $\begin{array}{l}\text { Sandstone horizon end alternating } \\
\text { way ( } 1-4 \mathrm{~m} \text { thickness. }\end{array}$ & $\begin{array}{l}5 \mathrm{R} 4 / 6 \quad \text { to } \\
5 \mathrm{R} 5 / 4\end{array}$ & & \\
\hline S3 & sandy clay $(2 \mathrm{~m}$ thickness & $5 \mathrm{R} 5 / 4$ & & \\
\hline F12 & $\begin{array}{l}\text { Horizon clay gravel and sandstone } \\
\text { fragments }(10-20 \mathrm{~cm} \\
\text { Thickness. }\end{array}$ & $5 \mathrm{R} 4 / 6$ & & \\
\hline F11 & $\begin{array}{l}\text { Horizon nodular clay, gastropods and } \\
\text { bivalves matrix ( } 1-2 \mathrm{~m} \text { thickness. }\end{array}$ & $5 \mathrm{R} 4 / 6$ & & \\
\hline F10 & $\begin{array}{l}\text { Silts with gastropods and bivalves } \\
\text { bioclast ( } 4 \mathrm{~m} \text { thickness. }\end{array}$ & $5 \mathrm{GY} 4 / 1$ & $\begin{array}{l}\text { Subhorizontal laminations, low } \\
\text { bioturbations, } 10 \mathrm{~cm} \text { thickness }\end{array}$ & $\begin{array}{l}\text { suspension deposit in a quiet } \\
\text { environment }\end{array}$ \\
\hline F9 & $\begin{array}{l}\text { Sand micaceous clay, gastropods and } \\
\text { bivalves mould }(2 \mathrm{~m} \text { thickness . }\end{array}$ & $5 \mathrm{GY} 4 / 1$ & horizontal laminations & $\begin{array}{l}\text { Planar bed flows with an average } \\
\text { hydrodynamic }\end{array}$ \\
\hline F8 & $\begin{array}{l}\text { Horizon clay nodular }\left(\begin{array}{llll}2 & \text { à } & 3 & \mathrm{~m} \\
\text { thickness. }\end{array}\right.\end{array}$ & $\begin{array}{l}5 \mathrm{R} 5 / 4 \\
5 \mathrm{Y} 7 / 6\end{array}$ & & \\
\hline F7 & $\begin{array}{l}\text { Micaceous sandy clay, coal, } \\
\text { gastropods and bivalves mould }(6 \mathrm{~m} \\
\text { thickness. }\end{array}$ & $5 \mathrm{G} 4 / 1$ & $\begin{array}{l}\text { fine horizontal laminations, } \\
60 \mathrm{~cm} \text { thickness }\end{array}$ & $\begin{array}{l}\text { Bed flows (Miall, 1978. with an } \\
\text { average planar hydrodynamics }\end{array}$ \\
\hline F6 & $\begin{array}{l}\text { Micaceous sandy clay, coal, } \\
\text { gastropods and bivalves mould }(4 \mathrm{~m} \\
\text { thickness. }\end{array}$ & $5 \mathrm{G} 6 / 1$ & horizontal laminations & \\
\hline F5 & $\begin{array}{l}\text { Mottled clay, plates and some } \\
\text { ferruginous nodules }(2-4 \quad \mathrm{~m} \\
\text { thickness. }\end{array}$ & $5 \mathrm{R} 4 / 6$ & $\begin{array}{l}\text { Fine horizontal laminations, } \\
60 \mathrm{~cm} \text { thickness }\end{array}$ & \\
\hline F4 & $\begin{array}{l}\text { Micaceous clay studded with } \\
\text { gastropods moulds and crusts of } \\
\text { hardened plates }(6 \mathrm{~m} \text { thickness. }\end{array}$ & $5 \mathrm{G} 6 / 1$ & horizontal laminations & $\begin{array}{l}\text { Suspension deposits in a weak } \\
\text { current environment with low } \\
\text { energy (Miall, } 1996 \text {. }\end{array}$ \\
\hline F3 & $\begin{array}{l}\text { Mottled sandy clay, presence of some } \\
\text { ferruginous nodules ( } 4 \mathrm{~m} \text { thickness. }\end{array}$ & $5 Y 6 / 1$ & horizontal laminations & $\begin{array}{l}\text { Deposit in the lower part of a } \\
\text { lower flow regime (Miall, 1978; } \\
\text { Postma, } 1990 \text {. }\end{array}$ \\
\hline $\mathrm{F} 2$ & $\begin{array}{l}\text { Clay with gastropods moulds and } \\
\text { coal }(4 \mathrm{~m} \text { thickness. }\end{array}$ & $5 \mathrm{G} 6 / 19+$ & horizontal laminations & \\
\hline $\mathrm{F} 1$ & $\begin{array}{l}\text { Compact clayrich muscovite and } \\
\text { charcoal fragments }(4-6 \mathrm{~m} \text { thickness. }\end{array}$ & $5 \mathrm{G} 6 / 1$ & horizontal laminations & \\
\hline
\end{tabular}




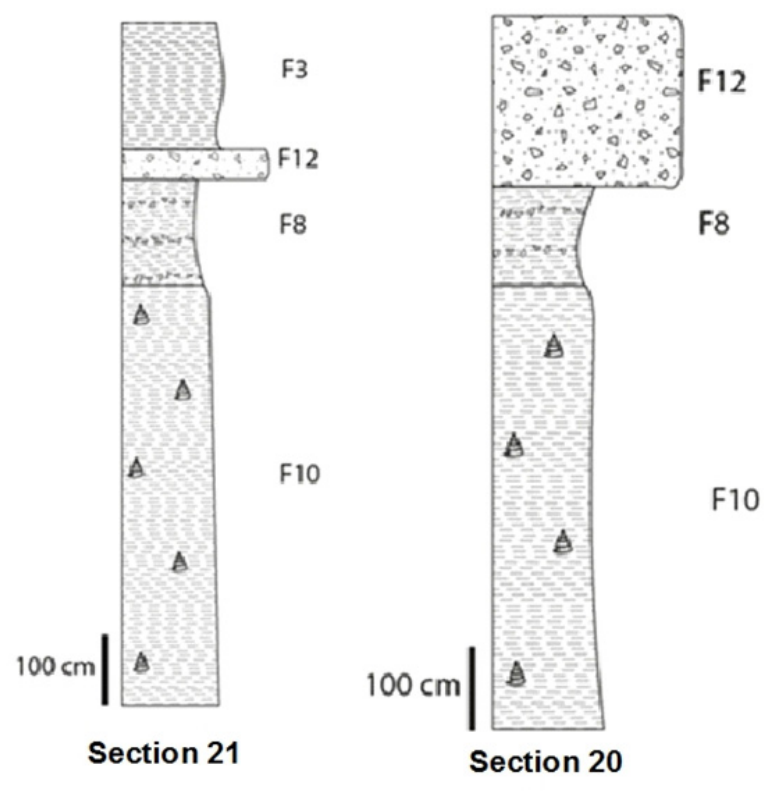

Figure 3. Representative lithologic sections at Ngoma Represents the lithological section of Ngoma area
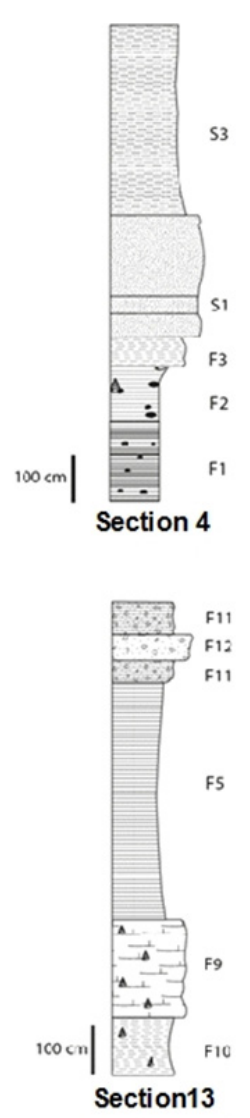
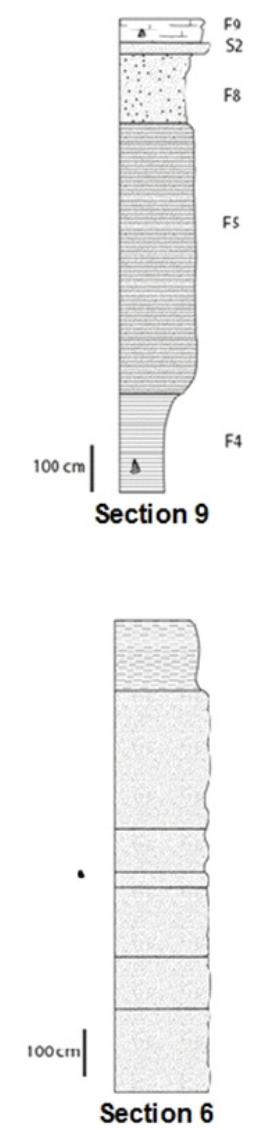
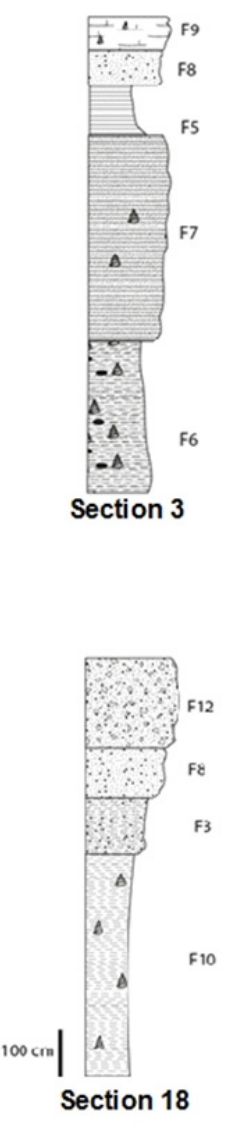

Figure 4. Representative lithologic sections at Bomkoul Represents the lithological section of Bomkoul area

\subsection{Bomkoul}

The survey data for Bomkoul are presented in Tables 2 to 4 and plots in Figures 5 to 7 . The surveys were carried out in dry weather (May) facilitating implementation. The investigation area is very accessible in some places 
and the device could extend to over $240 \mathrm{~m}$ at the surface.

Theoretical investigation depth is given by Barker's formula (Banton \& Bangoy, 1997) as:

Depth $=0.19 \times \mathrm{L}$ where $\mathrm{L}=\mathrm{AB}$ for each measuring point.

Table 2. Survey data S8 Bomkoul

\begin{tabular}{cccccc}
\hline $\begin{array}{c}\text { MEASURING } \\
\text { POINTS }\end{array}$ & $\mathrm{AB} / 2(\mathrm{~m})$ & $\mathrm{MN} / 2(\mathrm{~m})$ & $\begin{array}{l}\text { FACTOR } \\
1 / \mathrm{K}\end{array}$ & $\begin{array}{l}\text { RESISTANCE } \\
(\text { Ohm })\end{array}$ & $\begin{array}{l}\text { RESISTIVITY } \\
(\text { Ohm.m })\end{array}$ \\
\hline 1 & 1.5 & 0.5 & 0.1592 & 151.700 & 1112.5 \\
2 & 2.1 & 0.5 & 0.0766 & 84.828 & 989.5 \\
3 & 3 & 0.5 & 0.0364 & 51.431 & 836.5 \\
4 & 4.4 & 0.5 & 0.0167 & 21.298 & 745.8 \\
5 & 6.3 & 0.5 & 0.0081 & 12.389 & 687.5 \\
6 & 9.1 & 0.5 & 0.0039 & 7.177 & 548.5 \\
7 & 13.2 & 0.5 & 0.0018 & 3.747 & 204.5 \\
$7 \mathrm{~b}$ & 13.2 & 5 & 0.0213 & 39.220 & 204.5 \\
$8 \mathrm{~b}$ & 19 & 5 & 0.0095 & 15.244 & 125.6 \\
$9 \mathrm{~b}$ & 27.5 & 5 & 0.0044 & 5.778 & 112.3 \\
10 & 40 & 5 & 0.0020 & 1.834 & 125.4 \\
11 & 58 & 5 & 0.0010 & 0.394 & 413.2 \\
12 & 83 & 5 & 0.0005 & 0.394 & 849.3 \\
13 & 120 & 5 & 0.0002 & 0.041 & 1106.5 \\
\hline
\end{tabular}

ELECTRIC SURVEY CURVE

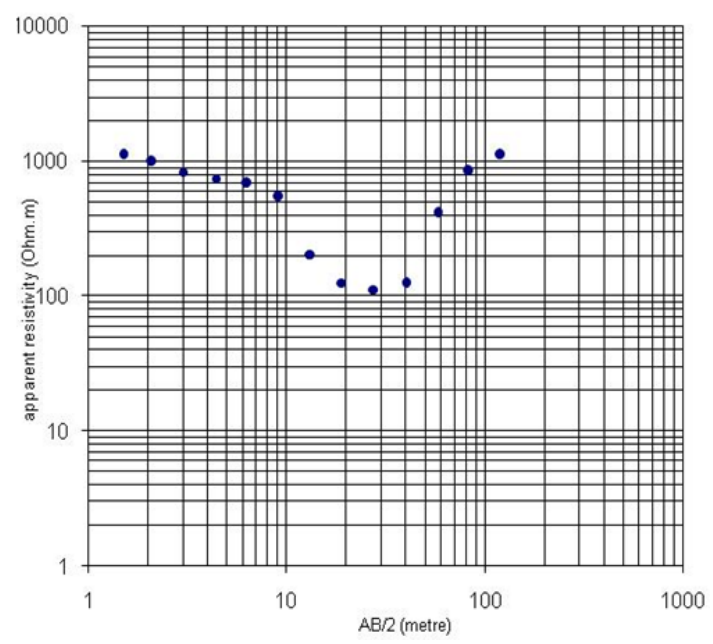

Figure 5. Projection of electric survey values S2 Bomkoul

Table 3. S10 Survey data Bomkoul

\begin{tabular}{cccccc}
\hline $\begin{array}{c}\text { MEASURING } \\
\text { POINTS }\end{array}$ & $\mathrm{AB} / 2(\mathrm{~m})$ & $\mathrm{MN} / 2(\mathrm{~m})$ & $\begin{array}{l}\text { FACTOR } \\
1 / \mathrm{K}\end{array}$ & $\begin{array}{l}\text { RESISTANCE } \\
(\text { Ohm })\end{array}$ & $\begin{array}{l}\text { RESISTIVITY } \\
(\text { Ohm.m) }\end{array}$ \\
\hline 1 & 1.5 & 0.5 & 0.1592 & 281.000 & 1764.7 \\
2 & 2.1 & 0.5 & 0.0766 & 130.120 & 1699.7 \\
3 & 3 & 0.5 & 0.0364 & 42.337 & 1163.2 \\
4 & 4.4 & 0.5 & 0.0167 & 14.422 & 865.4 \\
5 & 6.3 & 0.5 & 0.0081 & 5.106 & 632.3 \\
6 & 9.1 & 0.5 & 0.0039 & 1.512 & 392.0 \\
\hline
\end{tabular}




\begin{tabular}{cccccc}
\hline 7 & 13.2 & 0.5 & 0.0018 & 0.284 & 155.2 \\
$7 \mathrm{~b}$ & 13.2 & 5 & 0.0213 & 5.300 & 155.2 \\
$8 \mathrm{~b}$ & 19 & 5 & 0.0095 & 0.724 & 76.4 \\
$9 \mathrm{~b}$ & 27.5 & 5 & 0.0044 & 0.130 & 29.8 \\
10 & 40 & 5 & 0.0020 & 0.027 & 29.7 \\
11 & 58 & 5 & 0.0010 & 0.019 & 125.4 \\
12 & 83 & 5 & 0.0005 & 0.006 & 578.6 \\
13 & 120 & 5 & 0.0002 & 0.005 & 1116.5 \\
\hline
\end{tabular}

\section{ELECTRIC SURVEY CURVE}

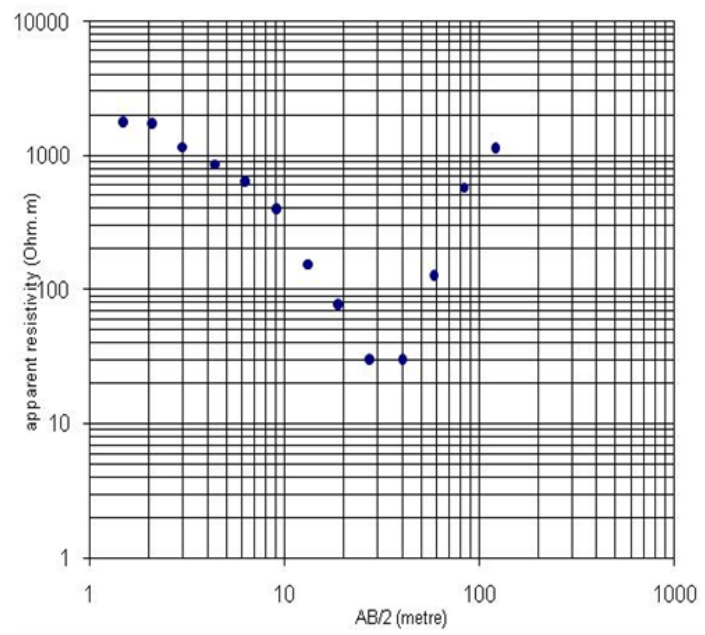

Figure 6. Projection of electric survey values S3 Bomkoul

Table 4. Survey data S11 Bomkoul

\begin{tabular}{cccccc}
\hline $\begin{array}{l}\text { MEASURING } \\
\text { POINTS }\end{array}$ & $\mathrm{AB} / 2(\mathrm{~m})$ & $\mathrm{MN} / 2(\mathrm{~m})$ & $\begin{array}{l}\text { FACTOR } \\
1 / \mathrm{K}\end{array}$ & $\begin{array}{l}\text { RESISTANCE } \\
(\mathrm{Ohm})\end{array}$ & $\begin{array}{l}\text { RESISTIVITY } \\
(\text { Ohm.m })\end{array}$ \\
\hline 1 & 1.5 & 0.5 & 0.1592 & 159.000 & 1132.5 \\
2 & 2.1 & 0.5 & 0.0766 & 69.500 & 907.8 \\
3 & 3 & 0.5 & 0.0364 & 29.574 & 812.5 \\
4 & 4.4 & 0.5 & 0.0167 & 10.374 & 622.7 \\
5 & 6.3 & 0.5 & 0.0081 & 2.919 & 361.5 \\
6 & 9.1 & 0.5 & 0.0039 & 0.617 & 160.0 \\
7 & 13.2 & 0.5 & 0.0018 & 0.137 & 74.8 \\
$7 \mathrm{~b}$ & 13.2 & 5 & 0.0213 & 2.400 & 74.8 \\
$8 \mathrm{~b}$ & 19 & 5 & 0.0095 & 0.197 & 20.8 \\
$9 \mathrm{~b}$ & 27.5 & 5 & 0.0044 & 0.119 & 18.5 \\
10 & 40 & 5 & 0.0020 & 0.055 & 27.3 \\
11 & 58 & 5 & 0.0010 & 0.052 & 54.4 \\
12 & 83 & 5 & 0.0005 & 0.075 & 160.6 \\
13 & 120 & 5 & 0.0002 & 0.254 & 1144.5 \\
\hline
\end{tabular}




\section{ELECTRIC SURVEY CURVE}

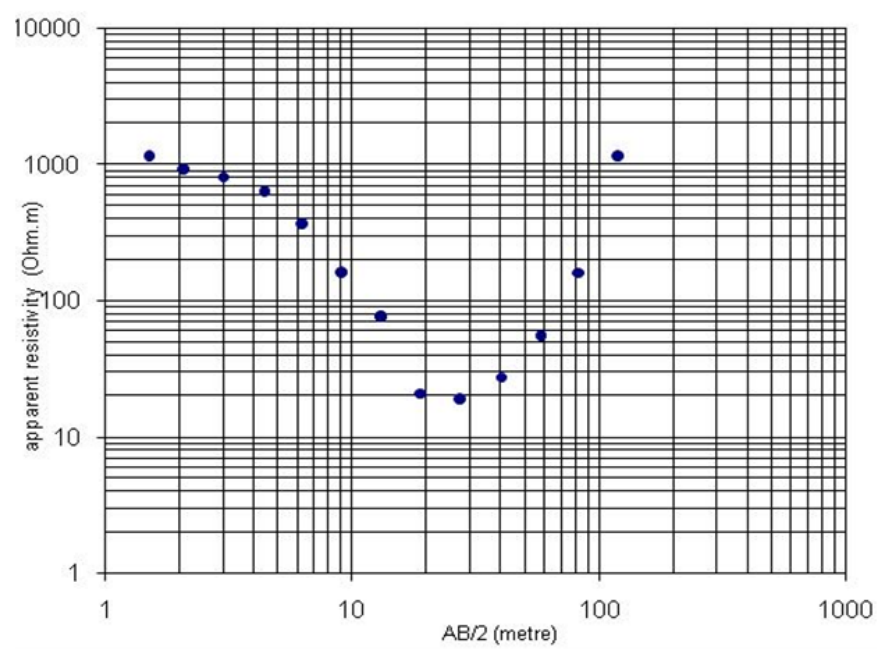

Figure 7. Projection of electric survey values S4 Bomkoul

\subsection{Ngoma}

The experiment was repeated in Ngoma, also in May. Several survey points have been made. The survey data is presented in Tables 5 to 6 and plots in Figures 8 to 9 .

Table 5. Survey data S27 Ngoma

\begin{tabular}{cccccc}
\hline $\begin{array}{c}\text { MEASURING } \\
\text { POINTS }\end{array}$ & $\mathrm{AB} / 2(\mathrm{~m})$ & $\mathrm{MN} / 2(\mathrm{~m})$ & $\begin{array}{l}\text { FACTOR } \\
1 / \mathrm{K}\end{array}$ & $\begin{array}{l}\text { RESISTANCE } \\
(\text { Ohm })\end{array}$ & $\begin{array}{l}\text { RESISTIVITY } \\
(\text { Ohm.m })\end{array}$ \\
\hline 1 & 1.5 & 0.5 & 0.1592 & 218.330 & 1371.1 \\
2 & 2.1 & 0.5 & 0.0766 & 175.140 & 975.5 \\
3 & 3 & 0.5 & 0.0364 & 205.710 & 768.5 \\
4 & 4.4 & 0.5 & 0.0167 & 539.640 & 587.4 \\
5 & 6.3 & 0.5 & 0.0081 & 13.676 & 401.5 \\
6 & 9.1 & 0.5 & 0.0039 & 3.895 & 126.7 \\
7 & 13.2 & 0.5 & 0.0018 & 0.147 & 80.5 \\
$7 \mathrm{~b}$ & 13.2 & 5 & 0.0213 & 18.176 & 74.5 \\
$8 \mathrm{~b}$ & 19 & 5 & 0.0095 & 2.231 & 38.3 \\
$9 \mathrm{~b}$ & 27.5 & 5 & 0.0044 & 0.167 & 38.3 \\
10 & 40 & 5 & 0.0020 & 0.945 & 128.4 \\
11 & 58 & 5 & 0.0010 & 0.054 & 458.7 \\
12 & 83 & 5 & 0.0005 & 0.111 & 998.7 \\
13 & 120 & 5 & 0.0002 & 0.278 & 1214.5 \\
\hline
\end{tabular}


ELECTRICAL SURVEY CURVE

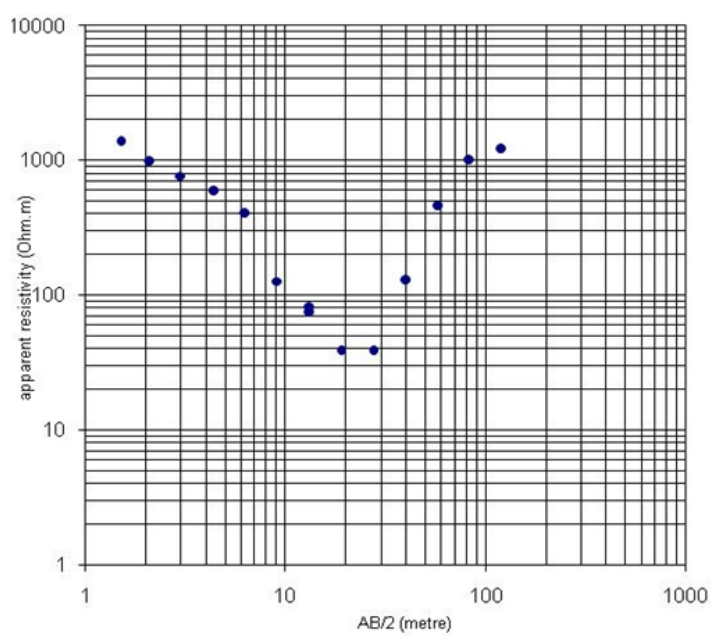

Figure 8. Projection of electric survey values S9 Ngoma

Table 6. Survey data S28 Ngoma

\begin{tabular}{cccccc}
\hline $\begin{array}{c}\text { MEASURING } \\
\text { POINTS }\end{array}$ & $\mathrm{AB} / 2(\mathrm{~m})$ & $\mathrm{MN} / 2(\mathrm{~m})$ & $\begin{array}{c}\text { FACTOR } \\
1 / \mathrm{K}\end{array}$ & $\begin{array}{c}\text { RESISTANCE } \\
(\text { Ohm })\end{array}$ & $\begin{array}{c}\text { RESISTIVITY } \\
\text { (Ohm.m) }\end{array}$ \\
\hline 1 & 1.5 & 0.5 & 0.1592 & 114.590 & 1263.2 \\
2 & 2.1 & 0.5 & 0.0766 & 48.031 & 978.6 \\
3 & 3 & 0.5 & 0.0364 & 20.511 & 563.5 \\
4 & 4.4 & 0.5 & 0.0167 & 6.164 & 369.9 \\
5 & 6.3 & 0.5 & 0.0081 & 1.749 & 216.6 \\
6 & 9.1 & 0.5 & 0.0039 & 0.321 & 83.1 \\
7 & 13.2 & 0.5 & 0.0018 & 0.053 & 46.6 \\
$7 \mathrm{~b}$ & 13.2 & 5 & 0.0213 & 0.994 & 46.6 \\
$8 \mathrm{~b}$ & 19 & 5 & 0.0095 & 0.003 & 56.7 \\
$9 \mathrm{~b}$ & 27.5 & 5 & 0.0044 & 1.576 & 112.5 \\
10 & 40 & 5 & 0.0020 & 1.362 & 207.5 \\
11 & 58 & 5 & 0.0010 & 0.774 & 412.5 \\
12 & 83 & 5 & 0.0005 & 0.504 & 721.1 \\
13 & 120 & 5 & 0.0002 & 0.275 & 1243.1 \\
\hline
\end{tabular}

ELECTRICAL SURVEY CURVE

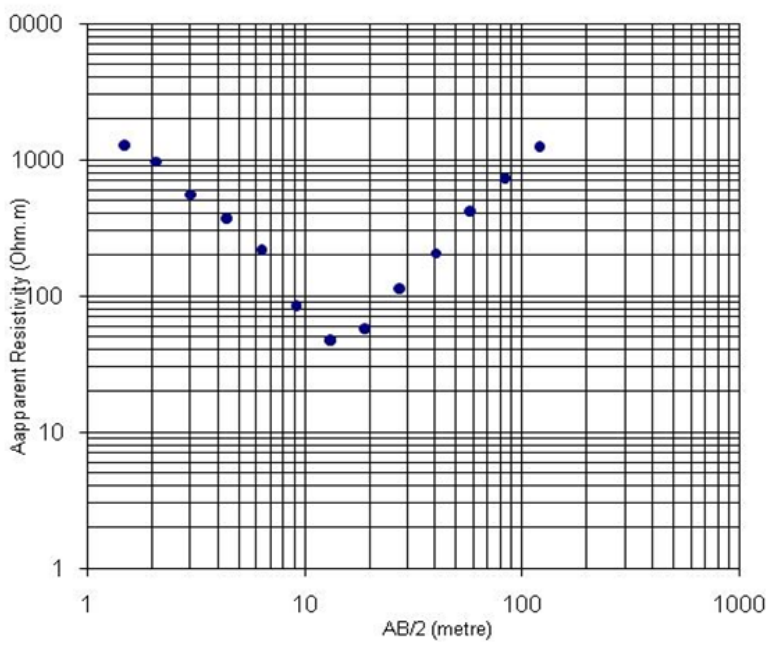

Figure 9. Projection of electric survey values S10 Ngoma 


\subsection{Bomkoul}

In Bomkoul region on the basis of lithological sections (Figure 3), the resistivities of 5 geoelectric layers were identified with the survey lead (Figures $9 \& 10$ ). The summary of interpretation is shown in table 7.

Table 7. Summary of the interpretation of the survey at Bomkoul

\begin{tabular}{llllll}
\hline Layer & Resistivity (ohm.m) & Layer thickness & (m) & Roof depth $(\mathrm{m})$ & Lithology of layers \\
\hline $\mathbf{1}$ & $(\mathbf{1 0 5 0}$ to 1800$)$ & $\mathbf{1}$ to 4 & $\mathbf{0}$ & Sandstone \\
2 & $(\mathbf{4 0 0}$ to 1050$)$ & 2 to 4 & 4 & clayey sand \\
3 & $(200$ to 700$)$ & 1 to 3 & 9 & Nodular clay \\
4 & $(\mathbf{8 0}$ to 550) & 2 to 4 & 11 & mottled clay \\
& & & & \\
5 & $(\mathbf{0}$ to 125) & 4 & 13 & sandy clay \\
6 & $(20$ to 130$)$ & 2 & 17 & Silts \\
7 & $(20$ to 70$)$ & 4 & 19 & Compact gray clay \\
\hline
\end{tabular}

\subsection{Ngoma}

At Ngoma, from lithological sections (Figure 4), the resistivities of 4 layers were determined accurately, the last layers were confusing because of their relatively low thicknesses (Figures 12 \&13). The summary of interpretation is shown in table 8 .

Table 8. Summary of the interpretation of the survey in Ngoma

\begin{tabular}{cclll}
\hline Layer & Resistivity (ohm)m) & Layer thickness (m) & Roof depth (m) & Lithology of layers \\
\hline 1 & $(1100$ to 1900$)$ & $(1$ to3) & 0 & clay gravel \\
2 & $(500$ to 1700$)$ & 4 & 3 & sandy clay \\
3 & $(400$ to 950$)$ & $(2$ to3) & 7 & nodular clay \\
4 & $(220$ to 520$)$ & 4 & 10 & silts \\
\hline
\end{tabular}

\subsection{Discussion}

Because of the great variability of facies, it would be risky to make correlations between the different surveys. However, it is possible to suggest a classification of soils according to their resistivity (Chilton \& Foster, 1995; Idris Nda \& Nwosu, 2006; Keller, G.V. and Frischanecht, F.C, 1966). Table 9 is a tentative classification of materials with their corresponding resistivities.

Table 9. Tentative classification of soils based on resistivity

\begin{tabular}{lc}
\hline Material & ResistivityValues (Ohm.m. \\
\hline Clay & 20600 \\
Sand & $>1000$ \\
Sand clay & 01000 \\
clayey sand & 7001900 \\
\hline
\end{tabular}

Thus for an application to Hydrogeology, favourable areas to search for underground water would present resistivities of about 400 to 1700 Ohm.m (Singhal \& Gupta, 2010).

In Bomkoul the aquifer zone consisting of an alternation of coarse sands and sandy clay, laying on a clay substratum of relatively low resistivity (about $725 \mathrm{ohm} . \mathrm{m}$ ), has resistivity values between 400 and $1050 \mathrm{Ohm} . \mathrm{m}$ (Figures $10 \& 11$ ). 


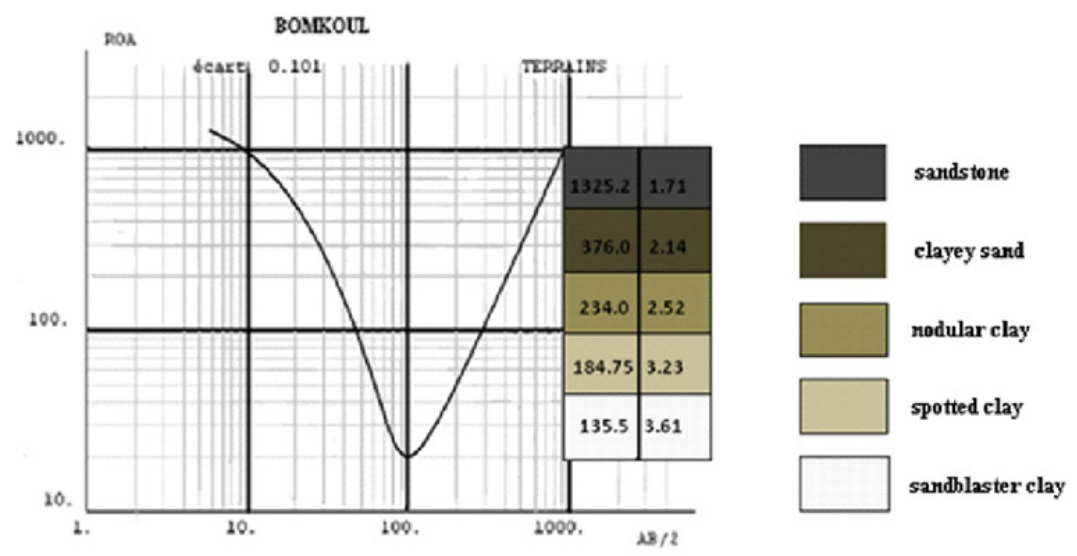

Figure 10. Multilayer interpretation of the electrical survey at Bomkoul

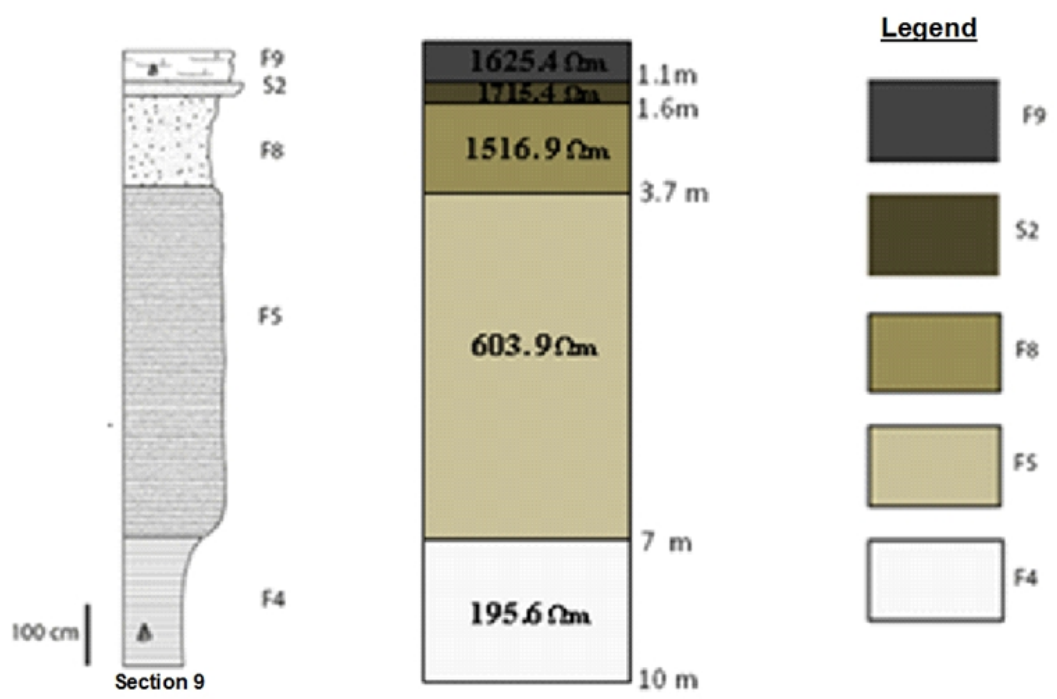

Figure 11. Geoelectric identification of different levels at Bomkoul

In Ngoma, the aquifer zone consists of sandy clay, coarse sand and sand located at $3 \mathrm{~m}$ depth resting on a clay substratum of low resistivity (1100 ohm.m approximately), has a resistivity ranging from 500 to $1700 \mathrm{Ohm} . \mathrm{m}$ (Figures $12 \& 13$ ).

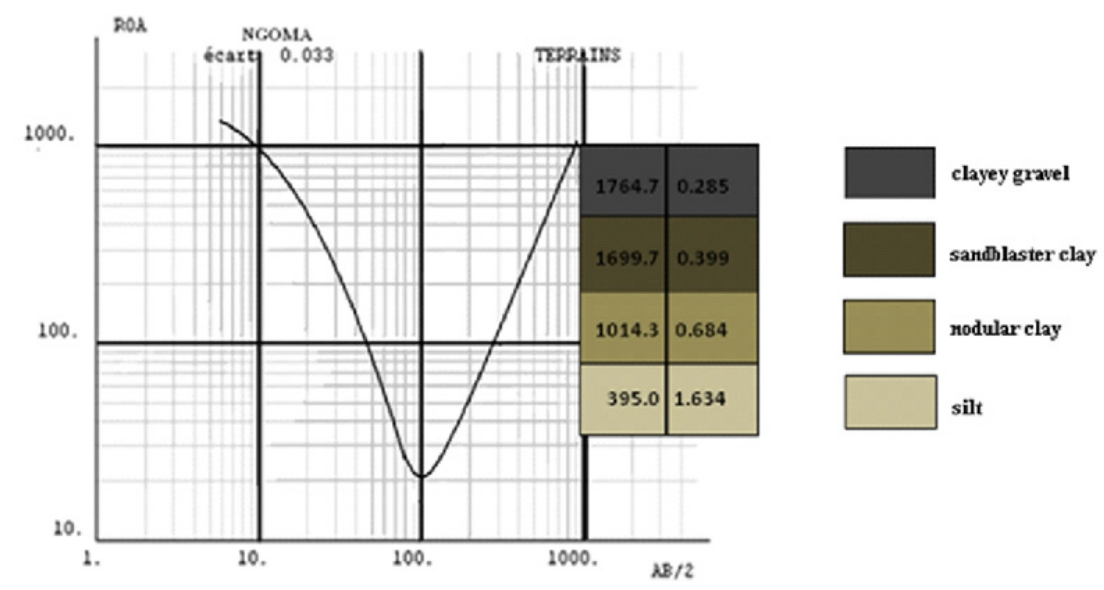

Figure 12. Multilayer interpretation of electrical survey in Ngoma 

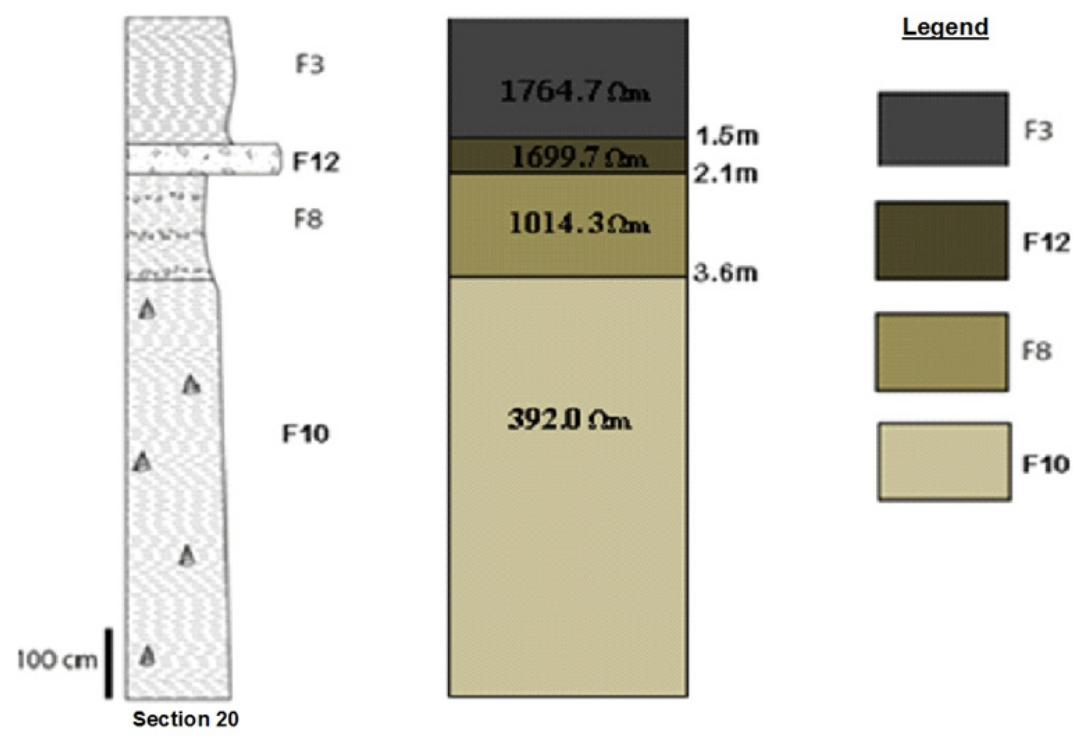

Figure 13. Geoelectric identification of different levels in Ngoma

As part of the search for clay areas for the installation of a landfill, for example, or a ceramic industry, favourable areas would have resistivity values between 0 and $1000 \mathrm{Ohm} . \mathrm{m}$, according to our investigations.

In Bomkoul and Ngoma regions mineralization of pyrite in the dark gray facies could end up in depths varying between 110 and $1100 \mathrm{~cm}$ with resistivity values between 40 and $1400 \mathrm{Ohm} . \mathrm{m}$. The soil facies is between 0 and $3 \mathrm{~m}$, therefore the resistivity varies between 550 and 1900 ohm.m while the depth of sedimentary facies is between 3 and $11 \mathrm{~m}$ with a resistivity ranging from 25 to $500 \mathrm{Ohm} . \mathrm{m}$.

\subsection{Conclusion}

The work done here was aimed at determining the actual resistivity of superficial formations of study sites in the Douala sedimentary sub-basin from vertical electric surveys. Several electrical surveys have been made in the areas of Bomkoul and Ngoma. The measuring instrument giving the apparent resistivity ground layers, the Qwseln software was used for the interpretation of the survey, and has enabled to obtain accurate resistivity of the crossed materials. It was therefore possible to suggest resistivity values for clays between 20 and $600 \mathrm{ohm} . \mathrm{m}$ and resistivity values greater than 1000 ohm.m for sand. These results generally show that the Matanda formation in the Douala sub-basin has very low resistivity, either sand or clay, nevertheless with much higher values for sand. Hypotheses were made as to the origin of this remarkable difference. But confirmation of the latter could be the subject to a future study.

Three points have emerged from this study: electric methods are well suited for the recognition of favourable hydrogeological areas; this method has helped to highlight the resistivity of the surveyed materials in each area. It is very suitable to formations of Douala basin as a results of the good resistivity contrast between clay and sand materials. Possible confusions may come from incomplete saturation or a handling error when running the survey.

But electric surveys have limitations since they fail to give a visualisation of the lateral continuity or not of crossed layers. Furthermore, the experimental determination of the values of the physical parameter of interest (in this case in this case, the resistivity) and its variations may reflect different situations, and only a good initial knowledge of the natural context allows you to choose the best geological interpretation. The geophysical study therefore cannot provide detailed information but gives a good overview of the surveyed site. Each geophysical method has its scope and limitations. It should therefore not be used for systematic surveys but should remain adapted to a specific problem to answer specific questions. However methods can be coupled to facilitate interpretations and enable to give a better approach and visibility of the desired aquifer.

It would therefore be appropriate to extend knowledge on the resistivity of the different formations in the study sites, make electrical trails which give a more qualitative approach and increase the lengths of $\mathrm{AB}$ line to increase the depth of investigation. It would also be beneficial to envisage the use of tomography which is a combination of vertical electric survey and electric trail. The latter used to define the geometry of aquifers faster. 


\section{Aknowledgements}

The authors are grateful to Mr Ebondji S., Djomeni A., Fowe P. and Waouke H. from the University of Douala who assisted with the field work. They also thank the Faculty of Science of the University of Douala that provided the geophysics apparatus.

\section{References}

Abrego, M. A. (2007). Application des méthodes géophysiques à la détection des sites précolombiens dans la région centrale de Panama et paramétrisation géoarchéologique dans le site hispanique de Panama Viejo. These de Doctorat, Université de Paris, 6, 143.

Astier, J. L. (1971). Géophysique appliquée à l'hydrogéologie, Masson, Paris. 278 p.

Banton, O., \& Bangoyl, M. (1997). Hydrogéologie multiscience environnementale des eaux souterraines. Aupelf, Quebec, p.460.

Barbier, J. L., \& Clement, G. (1983). Applications, intérêts, limites des méthodes de sondage à la reconnaissance des travaux souterrains. Expérience tirée des reconnaissances réalisées sur plus de $100 \mathrm{~km}$ de galeries du Canal de Provence. Bulletin de l'association internationale de Géologie de l'ingénieur, 159-166.

Batayney, A. T., \& Barjous, M. O. (2005). Resistivity surveys near a wastedisposal site in the Qasr Tuba area of central Jordan. Bull. Eng. Geol. Environ, 287-294.

Boiero, D., Goddio, A., Naldi, M., \& Yigite, E. (2010). Geophysical Investigation of a mineral groundwater ressource in Turkey. Hydrogeology Journal, 1219-1233.

Boudoukha, A. (2008). Identification des aquifères profonds par la prospection électrique, application à l'Est Algérien. Sciences \& Technologies, 47-52.

Bouguern, A., \& Baker, H. (2007). Méthodes géophysiques appliquées à la recherche d'eau souterraine dans l'Oued in Amguel Wilaya de Tamanrasset.. Bondy, France, 6eme Colloque GEOFCAN. pp. 34-43.

Bourenne, H., King, D., Isambert, M., \& Le Pacor, R. (1997). Utilisation de la prospection géophysique par résistivité pour l'étude de la variabilité spaciale du sol et des matériaux géologiques d'un site de petite Beauce. Colloque Géophysique des sols et des formations superficielles. BRGM, INRA, ORSTOM, UMPC, 23-28.

Bouvier, A., Croisy, P., \& Andrieux, P. (1997). Etude d'aquifères peu profonds à l'aide de sondages électriques et électromagnétiques. Colloque géophysique des sols et des formations superficielles.BRGM, INRA, ORSTOM, UMPC, 29-31.

Bouyalaoui, J. S. B. (2005). Essai d'optimisation de la capacité de retenue d'eau d'un lac par caractérisation géophysique du recouvrement argileux. African Journal of Sciences and Technology, 10-22.

Brownfield, M. E., \& Charpentier, R. R. (2006). Geology and total petroleum systems of the westcentral Coastal Province 7203., West Africa. U. S. Geological Survey Bulletin. 2207B, 52p.

Castany, G. (1982). Principes et méthodes de l'hydrogéologie.Bordas, Paris. 236 p.

Chapellier, D. (1987). Diagraphies appliquées à l'hydrogéologie.Lavoisier,Paris. 164 p.

Chiarelli, A. (2008). Identification des aquifères profonds par la prospection électrique, application à l'Est Algérien. Sciences \& Technologie, 47-52.

Chilton, P. J., \& Foster, S. (1995). Hydrogeological characterization and watersupply potential of basement aquifers in tropical Africa. Hydrogeology Journal, 3, 36-49. http://dx.doi.org/1007/s100400050061

Collin, J. J. (2004). Les eaux souterraines connaissance et gestion. BRGM Edition,Orléans. 176 p.

Comte, J. C. (2008). Apport de la tomographie électrique à la modélisation des écoulements densitaires dans les aquifères cotiers. These de l'académie d'AixMarseille, Université d'Avignon et des pays Vancluse. 200 p.

Detay, M. (1993). Le forage d'eau: Réalisation, entretien, réhabilitation. Masson,Paris, Milan, Barcelone Bonn. $440 \mathrm{p}$.

Dubois, J., \& Diament, M. (2005). Géophysique cours et exercice corrigés. Dunod (3rd ed.). Paris. 143 p.

Fetter, C. W. (1994). Applied hydrogeology. Printice Hall (3rd ed.). New Jersey. 598 p.

Gili, E., Mangan, C., \& Mudry, J. (2004). Hydrogeologie Objets, méthodes, applications. Paris, Dunod. 339 p.

Girard, J. F. (2010). Contribution à l'hydrogéophysique. Mémoire d'habilitation à diriger des recherches, 
Universisté de Strasbourg. $113 \mathrm{p}$.

Idris Nda, A., \& Nwosu, J. E. (2006). Groundwater Development Program in Parts of the Northern Sector of the Bida boasin. In Book of readings: $2^{\text {nd }}$ annual School of Science Education Conference, Federal University of technology, Minna: date, 19 th22 nd November, 2006: theme, challenges in science and technological advancement and economic reforms p.129.

Keller, G. V., \& Frischanecht, F. C. (1966). Electrical Methods in Geophysical Prospecting. Pergamon Press, New York, 519.

Meyer De Stadelhofen, C. (1991). Application de la géophysique aux recherches d'eau. Lavoisier, Paris. 133 p.

Singhal, B. B. S., \& Gupta, R. P. (2010). Applied hydrogeology of fractured rocks. Springer. http://dx.doi.org/10.1007/9789048187997

\section{Copyrights}

Copyright for this article is retained by the author(s), with first publication rights granted to the journal.

This is an open-access article distributed under the terms and conditions of the Creative Commons Attribution license (http://creativecommons.org/licenses/by/3.0/). 